The BDJ News section accepts items that include general news, latest research and diary events that interest our readers. Press releases or articles may be edited, and should include a colour photograph if possible. Please direct your correspondence to the News Editor, Kate Craig at the BDJ, 64 Wimpole Street WIG 8YS or by e-mail to bdj@bda-dentistry.org.uk

\section{Test tube teeth?}

There are early signs that the development of teeth in a test tube could be possible within the next few decades according to Dr Martyn Cobourne, a senior registrar in orthodontics at Guys' Hospital, GKT Dental Institute.

Dr Cobourne gave his speech on 'Test Tube Teeth' at a clinical day organised by the Specialist Practitioner Group of the British Orthodontic Society.

Dr Cobourne described research currently being carried out in the Department of Craniofacial Development at King's College, London under the leadership of Professor Paul Sharpe.

The team at KCL are able to manipulate genes that influence the initiation and patterning process during early tooth development. An important gene during initiation is Sonic Hedgehog, which encodes a signalling protein that can start up the tooth development process.

It may be possible to recreate the tooth development process in vitro in years to come, paving the way for the use of genetic engineering in the development of human teeth.

Dr Cobourne stressed that there is still much work to do before the process will be achievable for human teeth. However, exciting recent advances made in adult stem cell technology and in the artificial control of gene expression mean that genetically engineered teeth may not be totally in the realm of science fiction.

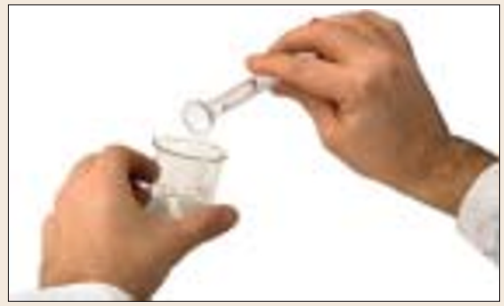

Test tube teeth - the way of the future?

\title{
Young researcher presents poster at House of Commons
}

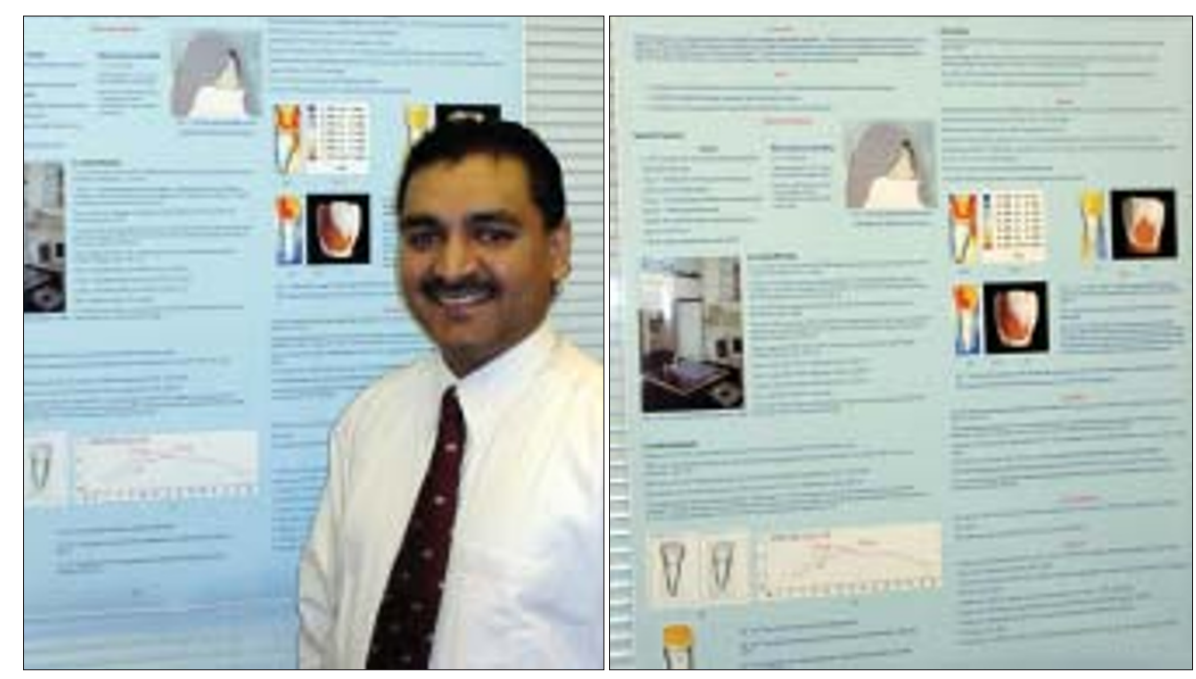

Research student George P. Cherukara presented the dental poster 'Quality of Tooth Preparations in Dentistry' at the 2003 Great British Research and RED Show at the House of Commons in March. Mr Cherukara's entry was the only poster from the field of dentistry at the event, the fifth annual reception for younger researchers.

Mr Cherukara is a research student at the Centre for Oral Biometrics, The Barts and the London, Queen Mary's School of Medicine and Dentistry, London. Supervised by Drs D Y D Samarawickrama and K G Seymour and supported by the technical expertise of Drs L Zou and G Davis, Mr Cherukara used co-ordinate metrology, Xray microtomography and finite-element analysis to assess tooth preparation quality for veneers and metal ceramic crowns. This team of researchers are comparing the various contemporary tooth preparation techniques with novel techniques to achieve theoretically ideal tooth preparations, thereby improving the durability and quality of the restorations provided. They have developed and tested new techniques, including dental burs as a result.

\section{NCAA appoint dental adviser}

The National Clinical Assessment Authority (NCAA) has appointed Janine Brooks as its dental adviser.

The NCAA is a special health authority set up in April 2001 to help the NHS in dealing with concerns about the performance of doctors and dentists. It provides a range of services from advice to ongoing support to NHS organisations as they tackle concerns, through to full performance assessment where necessary.

Janine's role at the NCAA will be to provide senior expertise and advice to employers who have concerns about the performance of individual dentists.

Janine currently works for the NHS
Information Authority and is a qualified dentist with experience in providing training and development. She is also an external verifier to City \& Guilds for oral healthcare.

Janine has worked in the Community Dental Services for 20 years. In 2002 she was appointed as part time Caldicott Guardian to the NHS Information Authority, ensuring it meets its legal and ethical obligations with regard to confidentiality.

The NCAA has only recently begun taking referrals about employed dentists working in hospitals and the community and Janine's role is pivotal to the development of this service. 


\section{DIARY}

June 2003

SAAD 10th International Dental Congress on Modern Pain Control

Date: 05.06.03-07.06.03Venue: Edinburgh International Conference Centre, Scotland Contact: Congress Secretariat

Tel: +44 (0)1413310123

Fax: +44 (0)1413310234

E-mail: info@saaduk.org

September 2003

Annual Meeting of the International Society for the Prevention of Tobacco Induced Diseases

Date: 29.09.03-01.10.03

Venue: Winnipeg, Canada

Contact: PTID-Society (Congress 2003)

Fax: + 1 (204) 789-3913

E-mail: PTIDSociety@AOL.COM

\section{October 2003}

9th Biennial Congress of the International

Academy of Periodontology

Date: 24.10.03-27.10.03

Venue: Cape Town International

Conference Centre

Tel: +27219389245

Fax: +27 219332649

www.sun.ac.za/iap2003

\section{May 2004}

BDA National Annual Conference

Date: 06.05.04-08.05.04

Venue: Bournemouth International Centre

Contact: Events Office,

British Dental Association

Tel: +44 (0) 2075634590

Fax: +44 (0) 2075634591

E-mail: events@bda.org

\section{GDC appoints visitors to dental schools}

The GDC has appointed a panel of 20 people to visit all UK dental schools between 2003-2005.

The Council has a statutory duty to ensure that the education of those training to be dentists in the UK is of a high standard, in order to protect patients. The GDC visits dental schools, and reports the visits to the Privy Council, which has the power to derecognise courses and examinations if they fail to meet the required standards.

Visits to UK dental schools will start in October this year and will be carried out by teams drawn from the panel. Each visiting team will include a basic dental science visitor, two clinical dental academic visitors, a lay visitor and a general dental practitioner visitor. Their job will include scrutinising course curricula and examinations.

The panel is made up of 12 academics, four GDPs and four lay people and will be co-chaired by Professor John Murray and Professor Colin Smith. The members of the panel are:

Academic visitors

(Basic dental sciences):

Dr Josie Beeley, University of Glasgow; Prof Samuel Cadden, University of Dundee; Dr Edward Odell, GKT, University of London; Professor Colin
Smith CBE, University of Sheffield.

\section{Academic visitors}

(Clinical dental academics):

Professor Ian Benington OBE, Queen's University of Belfast; Professor Alan Harrison, University of Bristol; Professor Malcolm Jones, University of Wales; Dr Iain Mackie, University of Manchester; Professor John Murray CBE, University of Newcastle; $\mathrm{Dr}$ Jonathan Pedlar, University of Leeds; Mr David Smith, University of Newcastle; Professor Paul Wright, Queen Mary, University of London.

General dental practitioner visitors: Mrs Shelagh Farrell, GDP, Kent;

Mrs Vivienne Lester, GDP, Hertfordshire; Mr Rajesh Majithi, GDP, London; $\mathrm{Mr}$ Denis Toppin, Dentist, member, GDC.

\section{Lay visitors}

(members of the General Dental Council):

Mr Peter Catchpole Lay member, GDC Mr Brian Coulter OBE Lay member, GDC Professor David Herbert Lay member, GDC Lady Sally Irvine Lay member, GDC.

All visitors will be given training before participating in visits. 


\section{Student clinicians rewarded}

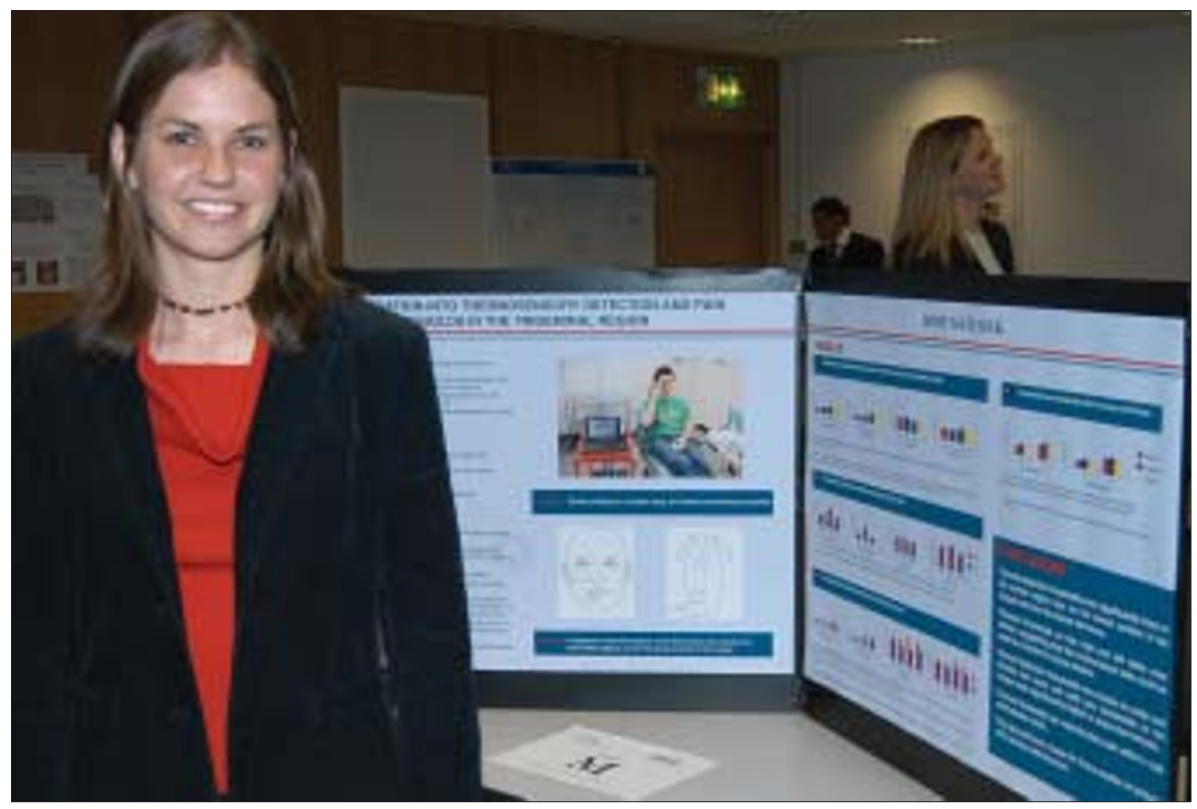

Rosalind Matusiak from Sheffield Dental School has been awarded first prize in the 26th BDA/Dentsply Student Clinician Programme.

Rosalind (pictured) won an all expenses paid trip to the annual ADA Conference in San Francisco for her investigation into thermosensory detection thresholds and thermal pain thresholds in different oral sites using Medoc thermosensory testing device.

Rosalind is no stranger to BDA awards last year she won the BDA/Dentist Provident Society Elective Award.

The second prize of $£ 350$ went to Laura Stevenson of the Turner Dental School, Manchester for her presentation entitled 'The relationship between third molar removal and temperomandibulat discorders'.

The Howard Tongue Memorial Award, an award for excellent communication skills, was awarded to Rachael Benson of the Leeds Dental Institute for her demonstration entitled 'A survey of demand for specialist restorative services'.

The Student Clinician Programme was founded to encourage research by undergraduate dental students worldwide and demonstrate successful collaboration between dental industry and profession.

The award has been administered by the BDA since 1978 and the standard of entries for this year's award was exceptionally high.

The adjudication took place at the Manchester International Convention Centre on 23rd April 2003. The adjudicators were Professor Newell Johnson and Professor John Drummond.

The winners were announced at 26th Annual BDA/Dentsply Dinner at The Lowry Centre, Manchester and all projects were displayed throughout the conference.

All the entrants received certificates and were offered the opportunity to become life members of SCADA (Student Clinicians American Dental Association).

\section{BDJ archives available on-line}

The $B D J$ is pleased to announce archives of the British Dental Journal covering the past 30 years are now available on-line.

The abstracts and full text of all articles published are available from 1999 onwards. The tables of contents for most issues are available from 1970 and selected abstracts are available from 1988 onwards. Access to all items is free to registered users one year after publication.

To access the archives visit the $B D J$ website at www.bdj.co.uk.

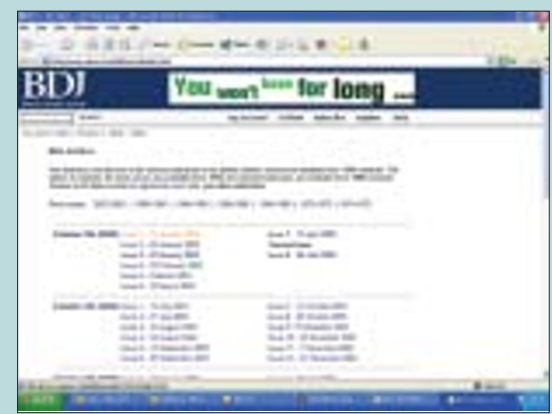

